\title{
Learning Styles, Motivation to Learn and Academic Performance of Grade Five Pupils
}

\author{
Dustin S. Catingub \\ Juaton Elementary School, Ormoc City District VI \\ Ormoc City Division, Ormoc, City
}

\begin{abstract}
This study was conducted to determine the level of learning styles, motivation to learn and academic performance of the Grade Five pupils. The relationship between the learning styles and academic performance was correlated as well as the relationship between motivation to learn and academic performance. The findings of the study served as bases for a proposed plan. This study utilized a descriptive-correlational design using the quantitative approach of research. It described, measured and interpreted the gathered data to provide answer to the sub problem. The method showed a descriptive task presenting the level of learning styles, motivation to learn and how the two affect the academic performance of the pupils. The result involved varied information regarding the present situations in the class. This also surveyed and assessed the data collected to come up with programs that are vital to the educational needs of the new generations of pupils. The study primarily involved the Grade Five pupils with different learning styles, motivation to learn and academic performance. The participants were the thirty seven (37) pupils of Juaton Elementary School that were under the advisory of the researcher. Purposive sampling was used to determine the target respondents in schools. The Grade Five pupils scored very high in visual and auditory learning styles while low in verbal and kinaesthetic learning styles. The overall mean of the four learning styles is high. The mean of their level of motivation is high. Their academic performance is satisfactory.
\end{abstract}

Keywords: Learning style; motivation; academic performance;grade five pupils

\section{Introduction}

Nowadays, some pupils have little to no concern about the things around them. They don't mind what behind about something as long as it doesn't affect them. In learning, they only learn if they want to. But, on the other side of the coin, there are some pupils who are eager to learn and know more about the things around them. They are so curious. Therefore, it tells that all pupils are different in all aspects.

Pupils are unique in the many ways they learn. They differ in their learning styles and how they are motivated to learn in order to improve their academic performance. These individual differences among the pupils give the teachers a hard time in distinguishing and creating activities suited for their abilities and interest. All of them are good in their own way but each one has a different style to learn faster than the other. All pupils also have different motivation to learn.Their reasons are personal, but knowing them will also help teachers in designing their lessons.

Teachers are also very eager to know the factors which can help enhance the pupils' learnings. Although some pupils are fast learners than others, there are also pupils who are underdeveloped and need time and effort more than others. Some pupils can easily learn through pictures, some are through listening, others are good in writing and reading, and while others learn through applying or doing (Fleming, 1987).

Everyone has a mix of learning styles. Some pupils may find that they have a dominant style of learning, with far less use of the other styles. Other pupils may discover thatthey can use different styles in different situations. There is no right or fixed mix. When teachers can identify these styles, the teachers can help the pupils develop theirless dominant styles, as well as further enhance styles that they already use well.

Since Grade Five is the first in the intermediate level, it is a great transition because this is the introduction of higher skills. That's why, the teachers need to know the skillswhich the pupils have already mastered and try to 
figure out what the pupils' weaknesses and strengths are and use their strengths to improve their weaknesses resulting to high academic performance (work.chron.com).

The purpose of this study is to show the learning styles, motivation to learn and academic performance of the Grade Five pupils of Juaton Elementary School. The study also aims to reveal the pupils develop motivation to learn and what their different learning styles are that help improve academic performance.

\section{Objectives of the Study}

This study aimed to correlate learning styles, motivation to learn to academic performance of Grade Five pupils in Juaton Elementary School.

Further, it sought to answer the following:

1. What is the level of learning styles of the Grade Five pupils in the aspects of:

1.1. Visual; 1.2 Auditory; 1.3 Verbal; and 1.4 Kinesthetic?

2. What is the level of motivation to learn among the Grade Five pupils?

3. What is the level of academic performance among the Grade Five pupils?

4. Is there a significant relationship between the following:

4.1. Learning styles and academic performance; and

4.2. Motivation to learn and academic performance?

\section{Significance of the Study}

Grade Five is the first intermediate level since it is when more complex skills are needed to be learned. To help facilitate easy acquirement of these skills, the Grade Five pupils have many ways to improve their academic performance because they have different learning styles and motivation to learn. And so, this will benefit the following:

Grade Five Pupils. Since learning comes all the time, the Grade Five pupils will know their own learning styles and how they can easily be motivated. Through this, they will spot their weaknesses and strengths to improve their academic performance.

Teachers. They will enhance the pupils' motivation to learn. Teachers can develop techniques that can help increase pupils' interest in learning. They will also acquire a clear idea with the intention of formulating various activities suited to the pupils' learning styles and interest.

School Heads. The role of the school heads in supporting and aiding teachers in dealing the pupils is much appreciated. With this research, they can appropriately apprehend the contemporary situation in the classroom for the reason that the pupils will be equipped with skills that will enhance their academic performance.

Supervisors. Guidelines and implementing programs come mostly from them since their involvement in improving the educational status is highly respected. They will upkeep and reinforce the teachers in dealing the pupils.

Parents. As education starts from home, the parents will know more the potential of their children. They will be the first key for the pupils to formulate the love for learning. They will see the improvements via thorough follow-up.

The Researcher. More knowledge will be gained by the researcher as he goes deeper into the process. A dedication towards helping other teachers dealing and improving the academic performance of the pupils with different learning styles and motivation to learn is reflected as the researcher's greatest achievement. inputs.

Future Researcher. They will have a guide when they pursue similar studies. This may serve as their 
The researcher chose to do the study in hopes that the study will help the researcher and the other teachers in handling pupils with different learning styles, motivation and academic performance. The researcher is a Grade Five teacher and eager to know more about the pupils' learning styles and motivation to learn and how these affect their academic performance.

\section{Theoretical and Literature Background}

This study is anchored on the learning styles theories of Neil Fleming's VARK Model and David Kolb's experiential learning. These theories state that every man has learning styles that suit him best. In other words, these propose that all people can be classified according to their style to learn. It is also anchored on the motivational theories such as Edward L. Deci's cognitive evaluation theory, B.F. Skinner's incentive theory, Abraham Maslow's hierarchy of needs, Frederick Herzberg's two-factor theory, Victor Vroom's expectancy theory and Walberg's theory of academic achievement.

\section{Learning Styles}

Fleming (1987) promotes his well-known model of learning styles, the VARK model. VARK stands for Visual, Auditory, Read (Verbal) and Kinesthetic. The learners learn easily according to their preferred style. Stating the truth that every learner is unique, learning styles define it all. The learners know their own learning styles develop their motivation to learn in the classroom. Developing an interest towards learning may result from modifying instruction method in line with their learning style.

Visual Learning is one of the components of the VARK model. Visual Learners tend to acquire knowledge by the present of grafts, charts, maps and diagrams. They learn through seeing and observing (Fleming, 1987). In this case, the learner tends to easily know through picturing the content especially the words that evoke a visual image. In addition, for visual learners, it is often far easily for them to recall images rather than words as they remember the image in their head better compared to remembering mere words.

Auditory Learning is more on listening. Auditory learners learn through listening (Fleming 1987). They learn best through verbal lectures, discussions, talking things through and listening to what others have to say. They interpret the underlying meanings of speech through listening to tone of voice, pitch, speed and other nuances. Written information may have little meaning until it is heard. These learners often benefit from reading text aloud and using a tape recorder. They rather listen most of the time than talking.

The Verbal (Linguistic) Learning Style involves both the written and spoken word. Verbal learners find it easy to express, both in writing and speaking. They love reading and writing. They like playing on the meaning or sound of words, such as in tongue twisters, rhymes, poems, limerick and the like. They know the meaning of many words, and regularly try to find the meaning of new words. They apply these new found words when talking to others.

Kinesthetic Learning Style requires touch, movement, or sometimes an emotional response (Sprenger, 2008). Kinesthetic learners tend to talk less because they prefer hands on activities. They use all their senses to engage in learning. They are easily motivated if they are giving attention and reward.

For some, the perfect learning style instrument is a fantasy. From the latter perspective, observation and interviews may be more likely than instruments to capture some of the broad learning strategies that learners adopt.Those who reject the idea of learning styles consider it more useful to focus on learners' previous experiences and motivation (Coffield et al., 2004). Learning styles have had a bad press. It seems that they are lauded and then attacked on an almost cyclical basis. It might be very hard to measure learning because it's difficult to describe learning in practical ways, especially if a person needs to know when learning occurs or to what it can be attributed (Fleming and Baume, 2006). Thus, this research is going to push through.

Learning Styles are defined as the characteristic cognitive, effective, and psychosocial behavior's that act as comparatively secure indicators of how learners understand, engage with, and respond to the learning 
environment. Learning styles are considered by many to be one factor of success in education. Confounding research and, in many instances, application of learning style theory has bear the myriad of methods used to categorize learning styles. There is not one currently method accepted, however there are alternative potential scales and classifications thatare being used. These scales and classifications are mostly similar than dissimilar and concentrate on environmental preferences, sensory modalities, personality types, and/or cognitive styles (Romanelli, 2009). Learning Styles are inborn character traits. They have effects on each moment and dimension in the life of individual (Boydak, 2006).

In David Kolb's experiential learning theory, it focuses on the learning process for the individual. One example of experiential learning is having a field trip in some historical places and learning through observation and interaction with the environment, as opposed to reading about those historical places from a book. Thus, one makes discoveries and experiments with knowledge first hand, instead of hearing or reading about others' experiences. Kolb's experiential learning theory consists of two levels: a four stage cycle of learning and four separate learning styles. Kolb's theory is additionally concerned with the learner's inner cognitive processes. It says that learning involves the acquisition of abstract concepts that can be applied flexibly in a variety of situations. In Kolb's theory, the impulse for the development of new concepts is provided by new experiences. New learning is gained through experiencing the actual situation (McLeod 2010). Learning can create knowledge through a series of experience (Kolb, 1984).

Kolb's experiential learning style theory is usuallycharacterized by a four-stage learning cycle where the learner undergoes all the stages. First,the Concrete Experience points out that a completely new experience of situation is experiencedor a reinterpretation of the current experience. Second, the Reflective Observation specifies that developinga new experience through observation to avoid any contradictions between experience and understanding. Third, the Abstract Conceptualization states that a reflection gives rise to a new idea, or a change of an existing abstract concept. Fourth, the Active Experimentation states that the learner applies them to the world around them to see what results. Kolb (1974) views learning as an integrated process that looks like a network with each stage being mutually supportive of and feeding into the next. It is possible to enter the cycle at any stage and follow it through its logical sequence (McLeod, 2010).

Kolb' experiential learning theory has four separate learning styles: Diverging (feeling and watching), Assimilating (watching and thinking), Converging (doing and thinking) and Accommodating (doing and feeling). Kolb expounds that some people naturally favor a certain distinct learning style. Various factors influence a person's preferred style. For example, social environment, educational experiences, or the basic cognitive structure of the individual affect the persons' style (McLeod, 2010).

In diverging (feeling and watching) under Kolb's experiential learning theory, the people are able to look at things from different perspectives. They are sensitive. They prefer to watch rather than do, tending to gather information and use imagination to solve problems. They are expert at viewing specific situations in several differentperspectives. One example is when a person observes the painting, he thinks behind of what he has seen. In the person's mind, there are some additional thoughts. Kolb described this style as diverging since these people do better in situations that involve ideas like brainstorming. They have wide cultural interests and like to collect information. They are friendly, imaginative, emotional and artistic. People with the diverging style prefer to work in groups, to listen with an open mind and to receive personal feedback (McLeod, 2010).

The accommodating learning style is 'hands-on', and depends on intuition rather than logic. These people use other people's analysis, and favor to take a practical, experiential approach. They are involved to new challenges and experiences, and to carry out plans. They commonly act on 'gut' instinct rather than logical analysis. People with an accommodating learning style will be apt to rely on others for information than carry out their own analysis. This learning style is customary within the general population (McLeod, 2010).

The Assimilating learning preference is for a concise, logical approach. Ideas and concepts are more important than people. These people require good clear explanation and clarification rather than practical opportunity. They are good at understanding and organizing broad information in a clear logical format. They are 
less focused on people and practical methods butmore involved in ideas, theories and abstract concepts. The Assimilating learning preference is very important in the fieldsof information and science. In formal learning situations, people with this style prefer readings, lectures, exploring analytical models, and having time to think things through (McLeod, 2010).

In converging learning style, the people can solve problems and utilize their learning to find solutions to the practical issues and concerns. The people with a converging learning style are best at discovering practical applications for ideas and theories. They would favor practical tasks and are less interested withsocial aspect. A converging learning style improves practical skills. People with a converging style like to experiment with new ideas, to simulate, and to work with practical applications (McLeod, 2010).

It is very important to know oneself or a person's learning style so that it allows learning to be more focused on the preferred method. It is stated that everyone reacts to and requires the stimulus of all types of learning styles to a greater or lesser degree. The most important thing is that the learning styles suited in the given circumstances. (McLeod, 2010).

Both learning styles theories of Fleming and Kolb have many characteristics in common. They may differ in names but indeed they have the same meaning. All people around have different styles in acquiring new knowledge. They learn by their preferred styles. They can also acquire two or more learning styles but their dominant style stands out. Their less dominant styles can be improved, too, for circumstances which require it.

\section{Motivation to Learn}

Motivation is one of the most important factors that educators can consider in order to enhance learning. Motivation can be either intrinsic or extrinsic in which the learners learn by willing interest or by being motivated by others. In addition (Cools et al., 2014), if the teachers want to stimulate learners, intrinsic motivation, group activities do not seem to be the right approach. Motivation occurs depend of what learning styles that the learners prefer.

Motivation states a desire, need, or ambition that contributes to and explains behavioral changes. In overall, motivators provide some sort of incentive for completing a task and prov. Another definition from Lucas (2010) explains it as a force "acting either on or within a person to initiate behavior." In addition to biological motives, motivations can be either intrinsic (internal factors/within self) or extrinsic (external factors/by others). Kenner's incentive theory debates that people are primarily extrinsically motivated-meaning that most motivations come from extrinsic sources like a person who determines to become somebody in the future because of someone that acts as his or her inspiration (www.boundless.com).

B.F. Skinner's incentive theory states that motivation comes through rewards and incentives. The individual can be fully motivated expecting for the incentives in return. Incentive theory argues that before the person develops intrinsic motivation at work he or she must be extrinsically motivated. The actions of the people are mostly extrinsically motivated. They are more motivated to perform the activities if they obtain a reward, rather than simply enjoying the activities themselves. Their views towards work depend on their motivation (www.boundless.com).

Deci's cognitive evaluation theory speaks that motivation has two systems. These are the intrinsic motivation and the extrinsic motivation. When the individual is intrinsically motivated, he or she perform the task with self-satisfaction without aiming for rewards. However, in the opposite sides, the extrinsically motivated individuals work hard and expect for rewards. The individuals do good things in work to make their boss proud. When there are unbalanced situations between intrinsic and extrinsic motivations, the latter overpowers the intrinsic motivation. Too much extrinsic motivation can reduce the individuals' intrinsic motivation. The people tend to lose their intrinsic motivation especially when others convince them to do something for reward. Example is when the boss always reminding his or her subordinates to perform good for the company so that promotion or salary increase will be granted. The subordinates work hard in order to promote and to increase salary resulting to the losing their feelings on how they value their work (www.analytictech.com).

(C) 2020, IJSMS Page 53 
In incentive theory, Skinner and other behaviorists believe that a person will more likely to do an action that is positively received, while he or she will more likely avoid an action that is negatively received. This is the effect of positive and negative incentives. The reward depends on the person's action. The persons tend to do good things for good rewards. They also do it for promotions by working hard to satisfy their superior's expectation. Those mentions are positive incentives. As opposed to positive incentives, negative incentives are provided in order to fix an individual's mistakes and errors for the sake of attaining satisfying results. More often than not, negative incentives are given if the positive incentives do not work, conditioning a person to act to avoid such negative incentives. These include job demotion, penalties and fines (www.explorable.com).

Abraham Maslow's hierarchy of needs concludes that motivation occurs when individual attains his or her needs. The satisfaction of needs can affect the behavior of individual and resulted to have a motivation in life. Maslow's hierarchy of needs have five levels in which the needs at the bottom are the most urgent and need to be satisfied before attention can be paid to the others. The first and bottom part of the hierarchy are physiological needs like food, water and sex. Food, water, shelter and clothes must be satisfied first because they are daily needs. Sex doesn't mean that the individual must urge to do this before going to the next level of needs. This theory implies that sex is for the survival of the species nothing more and nothing less and that's why it falls under the level of physiological needs.

The second are safety needs; freedom from war and violence, job security and health. These are safety since they talk about the security of the individual. The third level is belongingness. The individual wishes to belong in a group, to have family and to have friends for the reason that no man is an island. The fourth level is esteem. The individual needs to be recognized among others and the needs to have responsibility in the community. The fifth and final level is self-actualization. The person wants to have self-fulfillment. The above needs affect the motivation of a person on how he acts to achieve his or her goals in life (www.analytictech.com).

According from Frederick Herzberg's two-factor theory, there are two factors that affect motivation. One is hygiene factors. These are factors whose absence motivates, but whose presence has no apparent effect. There are things that have lost, the people become dissatisfied and try to get them back. The very bad example of this is drug addiction. When the individuals stop using drugs, they undergo withdrawal syndrome. The people become sick when drug is absent. They cannot live without it because they depend on it. A good example is when the people needs food. They try to do things to live. For instance, finding a job is a good idea in order to satisfy their needs.

Hygiene factors have relationship to the basic level of Maslow's hierarchy of needs. The second factors are the motivators. These are factors whose the presence of something has a great affect to the individuals. But when that something is absent, it doesn't affect or hurt the people. A good example is when a person has graduated with honor. This means that person has great ability because he or she is an honor student. The same with an individual who has graduated without an honor but still that individual has finished his or her study. As long that individual has finished, he or she can find job. Motivators have relationship with the higher levels of Maslow's hierarchy of needs (www.analytictech.com).

In Vroom's expectation theory, motivation is the product when the expectancy, instrumentality and valence have met. Thus, making the equation M=E x I x V. Motivation is the extent of the person will be motivated by the circumstances they encounter. The three elements of expectation theory of motivation are: (1) Expectancy is the person's expectation or perception that effort will result to performance. (2) Instrumentality is the person's perception of the performance must be rewarded. There might be positive or negative incentives towards the person depend on how good or bad his or her performance. And, (3) Valence is the outcome of the performance's reward or punishment. It has direct proportional relation to the motivation. When the reward is high, the motivation is high. When the reward is low, the motivation is low (www.anlytictech.com).

\section{Academic Performance}

The Walberg's theory of academic achievement/ performance is the degree to which a learner, teacher or institution has accomplished their educational objectives. It helps to shape the career of the individual in the future. 
The psychological research has concentrated on identifying predictors of academic performance, with the information and effort evolving as the fundamental determinants. Walberg proposes expanding on the traditional set of predictors by adding a third agency: intellectual curiosity. The series of path models that are based on a metaanalytically obtained correlation matrix showed that (a) the intelligence is the only most powerful predictor of academic performance; (b) the impacts of intelligence on academic performance are not facilitated by character traits; (c) the intelligence, Conscientiousness (as an indicator of effort), and Typical Intellectual Engagement (as an indicator of academic curiosity) are the direct, correlated predictors of academic performance; and (d) the additive analytical impact of the character traits of academic curiosity and effort rival that the impact of intelligence. (http://journals.sagepub.com)

When the word academic performance comes out in mind, the learners think about average. Learners often reflect grades first when evaluating academic performance. This involves schools, which use ranking of the students by their average, granting special academic awards such as valedictorian, salutatorian and honorable mentions for those who graduate with honors in their class. Scholarship organizations and universities also begin to look at grades. When hiring new applicants, some employers focus on the grades as bases. Grades bring more weight in some businesses, particularly in the technical professions such as law, medicine and finance. Other industries place less importance on general average, particularly creative professions such as writing or art and occupations such as sales where people skills are more vital than technical knowledge. (www.work.chron.com)

Some of the brightest students don't earn good grades but are extremely well-rounded, succeeding at everything in extra-curricular activities. The ability to master a varied set of skills illustrates intelligence, curiosity and persistence, qualities attractive to universities and employers. Some colleges will acknowledge and even award scholarships for students who gained average grades but exhibit a consistent pattern of accomplishment by frequently learning new skills. Many businesses also perceive this as a selling point, thinking these candidates are willing to learn and will be easy to train. (www.work.chron.com)

From the research of Ghaedi and Jam (2014), it reveals that visual learning style is more prefer. It shows that there is significance relationship between the learning styles and motivation for higher education. Another study from Cools, Vanderheyden and Backhus (2014) tells about the impact of the student style differences and motivation on learning outcomes in management education. The same study of Lucas, Pulido, Miraflores, Ignacio, Tacay and Lao (2010) concludes that motivation factors influence learning. While the studies of Carbonel (2013) and Tonog (2015) found out those learning styles have great affect to the learners' performance in school. The above studies deal about the higher level so the researcher eagers to see and to delve more in elementary level.

This part of the study discusses the above mentioned theories and relevant literatures connected with the study of the learning styles and motivation to learn of the learners and how these affect their academic performance. This credits also the works that has been published on a topic by accredited scholars and researchers. All this would allow the researcher to view the field and position of the research within the framework. Likewise, this justifies the reason for the study. It is the knowledge of the field that allows one to identify the gap, which the research could fill. Concurrently, it allows the researcher to establish what level of learning styles and motivation to learn with each learner has.

\section{Methodology}

This study utilized a descriptive-correlational design using the quantitative approach of research. The learning styles, motivation to learn and academic performance of the pupils were described quantitatively. The relationship between these variables was also tested, measured and established, thus correlational. The quantitative approach of research was applied since all data were gathered using a semi-structured interview guide that the researcher compiled for the pupils.

This study was conducted in Juaton Elementary School, Juaton, Ormoc City. The school is under the supervision of District VI, Ormoc City Division. It is a small school consisting of seven (7) teachers from 
Kindergarten to Grade Six. The school has one hundred thirty one (131) males and one hundred eighteen (118) females, the total of two hundred forty nine (249) pupils. It has seven (7) classrooms and one (1) computer room.

The research respondents werethirty seven (37) Grade Five pupils, seventeen (17) males and twenty one (21) females. The selection used was universal since all the Grade Five pupils in Juaton Elementary School were the respondents of the study.

\section{Results and Discussion}

This part includes the presentation, analysis and interpretation of data gathered which determined the level of learning styles, motivation to learn and academic performance of the Grade Five pupils. The variables: learning styles and academic performance have significant relationship as well as the relationship between motivation to learn and academic performance is also significant.

The thirty seven (37) Grade Five pupils of Juaton Elementary School were the participants of this study. The participants answered the given questionnaires to measure the level of learning styles and motivation to learn. In measuring the level of academic performance, the researcher used the pupils' general average of the four quarters or grading periods to make the data more reliable. This study also answered the significance relationship between the variables - learning styles and academic performance; motivation to learn and academic performance.

In the first part of the questionnaire, a standardized tool used to measure the level of learning styles was the VARK Questionnaire developed by Neil D. Fleming. The results are shown in table 1.

In the second part of the questionnaire, a standardized tool used to measure the level of motivation to learn of the Grade five pupils, the Revised Study Process Questionnaire (R-SPQ-2F) formulated by Mark Dowling and Griffith College Dublin.

Table 1. The Level of LearningStylesof Grade Five Pupils

\begin{tabular}{|l|c|c|}
\hline \multicolumn{1}{|c|}{ Instructional Skills } & Weighted Mean & Interpretation \\
\hline Visual & 3.56 & Very High \\
\hline Auditory & 3.32 & Very High \\
\hline Verbal & 2.32 & Low \\
\hline Kinesthetic & 2.00 & Low \\
\hline Grand Mean & $\mathbf{2 . 8 0}$ & High \\
\hline
\end{tabular}

In table 1, the visual learning style has the highest weighted mean: 3.56 which means very high and followed by auditory is 3.32 , which also interpreted as very high. However, the verbal weighted mean is 2.32 which means low, the same as the kinesthetic weighted mean is 2.00 which is considered also as low. Therefore, the learning styles dominant in the Grade Five pupils are the visual and auditory while the verbal and kinesthetic learning styles are the less dominant. The grand mean of the Grade Five pupils' learning styles is 2.80 interpreted as high.

According from Fleming (1987), learners learn easily with their preferred style. In visual learning style which is the dominant style, the Grade Five pupils tend to learn through seeing. They think in pictures and need to create vivid mental images to retain information. They love looking at maps, charts, pictures, videos, and movies. They have visual skills which are demonstrated in puzzle building, reading, writing, understanding charts and graphs, a good sense of direction, sketching, painting, creating visual metaphors and analogies (perhaps through the visual arts), manipulating images, constructing, fixing, designing practical objects, and interpreting visual images.

The lowest among the learning styles is kinesthetic which interpreted also as low. The Grade Five pupils are still improving in manipulative skills and other activities related in procedures and demonstration. They have lesser skills demonstrated in physical coordination, athletic ability, hands on experimentation, using body language, crafts, and acting, miming, using their hands to create or build, dancing, and expressing emotions through the body. 
The result of the study shows that visual and auditory learning styles are dominant among the Grade Five pupils while the verbal and kinesthetic styles are less.

During class, the teachers must use different activities to their pupils. An activity that suits to the learning styles and interest of the pupils can affect most their academic performance. When the pupils preferred style is visual, teachers should not present activities that are more on manipulative skills and demonstration. Instead, the teachers must use film showing, visual images or pictures and maps in teaching. When the pupils preferred style is auditory, the teachers must use lectures, audio-tapes and reports that increase the listening skills of the pupils. When the pupils' ideal style is verbal, the teachers must use reports, storytelling and reading aloud. If the pupils' dominant learning style is kinesthetic, the teachers include demonstration and manipulative skills in teaching. In this case, the pupils' academic performance is associated to their learning styles. However, when the pupils in the class have different learning styles or heterogeneous, the teachers need to be resourceful and use varied activities that can suit the learning styles of the pupils.

Table 2. The Levelof Motivation to Learn of Grade Five Pupils

\begin{tabular}{|l|c|c|}
\hline \multicolumn{1}{|c|}{ Behavioral Skills } & Weighted Mean & Interpretation \\
\hline Strongly Agree & 3.48 & Very High \\
\hline Agree & 3.02 & High \\
\hline Disagree & 1.97 & Low \\
\hline Strongly Disagree & 1.30 & Very Low \\
\hline Grand Mean & $\mathbf{2 . 4 4}$ & High \\
\hline
\end{tabular}

In table 2, the grand mean of the level of motivation to learn of the Grade Five pupils is 2.44 which interpreted as high. This means that most of the Grade Five pupils are interested to learn.

In improving the motivation to learn of the pupils, the teachers must conduct a series of activities that can arouse their interest towards the lesson. The teachers include opening activities that jive to the lesson's objective and can cause the pupils more focus on the lesson. The opening of the lesson must be an eye catcher to the pupils so they focus until the lesson has ended. Their interest nowadays can easily be distracted because of many factors like modern gadgets and peers that's why the teachers must be initiative to overcome those distractors. It can be coped up by using many interventions like using different multi-media in teaching and using interactive learning like peer teaching/tutoring. In terms of intensive motivation, rewards will be given for those pupilswho excel well in the class. The teachers know the best because they have the biggest part in moulding the pupils.

Table 3. Academic Performance of the Pupils

\begin{tabular}{|l|l|c|c|}
\hline \multirow{2}{*}{ Range } & \multirow{2}{*}{ Descriptor } & \multicolumn{2}{c|}{ Grade 5 Pupils } \\
\cline { 3 - 4 } & & Frequency & Percentage \\
\hline $90-100$ & Outstanding & 5 & 14 \\
\hline $85-89$ & Very Satisfactory & 9 & 24 \\
\hline $80-84$ & Satisfactory & 18 & 48 \\
\hline $75-79$ & Fairly Satisfactory & 5 & 14 \\
\hline Below 75 & Did Not Meet Expectation & 0 & 0 \\
\hline Total & & 37 & 100 \\
\hline Combined Mean & $\mathbf{8 3 . 1 9}$ & Satisfactory \\
\hline
\end{tabular}

Table 3 presents the academic performance of the Grade Five pupils. There were5 (14\%) pupils who achieved the outstanding grades range from $90-100 ; 9$ (24\%) very satisfactory grades from $85-89 ; 18(48 \%)$ satisfactory grades from $80-84 ; 5(14 \%)$ fairly satisfactory grades from $75-79$. The combined mean of the academic performance of the Grade Five pupils is 83.19 which read as satisfactory. 
The highest percentage of frequency is the pupils who have satisfactory grades, followed by the pupils who have very satisfactory grades and the lowest percentage is the pupils who have the outstanding and fairly satisfactory grade. This means that the Grade Five pupils are heterogeneous.

To improve the academic performance of the pupils, the teachers must use different interventions. The academic performance of the pupils depends on how the teachers handle their pupils and how they facilitate the teaching-learning process. If the pupils decrease their academic performance, the teachers must conduct a constant and thorough remediation to elevate the performance of the pupils.

Table 4. Test of Relationship between Learning Styles and Academic Performance; Motivation to Learn and Academic Performance

\begin{tabular}{|c|c|c|c|c|c|}
\hline $\begin{array}{l}\text { Variables } \\
\text { Correlated }\end{array}$ & $\mathbf{r}$ & $\begin{array}{c}\text { Computed } \\
\text { value or } t\end{array}$ & $\begin{array}{l}\text { Table Value } \\
\quad @ .05\end{array}$ & $\begin{array}{l}\text { Decision on } \\
\text { Ho }\end{array}$ & Interpretation \\
\hline $\begin{array}{c}\text { ACADEMIC } \\
\text { PERFORMANCE \& } \\
\text { VISUAL STYLE }\end{array}$ & 0.37 & 1.041 & 0.228 & Reject Ho & $\begin{array}{l}\text { Significant Relationship } \\
\text { (Moderate Positive } \\
\text { Relationship) }\end{array}$ \\
\hline $\begin{array}{c}\text { Academic Performance } \\
\& \\
\text { Auditory Style }\end{array}$ & 0.33 & 0.892 & 0.228 & Reject Ho & $\begin{array}{l}\text { Significant Relationship } \\
\text { (Moderate Positive } \\
\text { Relationship) }\end{array}$ \\
\hline $\begin{array}{c}\text { Academic Performance } \\
\text { \& Verbal }\end{array}$ & 0.30 & 0.667 & 0.228 & Reject Ho & $\begin{array}{l}\text { Significant Relationship } \\
\text { (Moderate Positive } \\
\text { Relationship) }\end{array}$ \\
\hline $\begin{array}{c}\text { Academic Performance } \\
\text { \& Kinesthetic }\end{array}$ & 0.30 & 0.664 & 0.228 & Reject Ho & $\begin{array}{c}\text { Significant Relationship } \\
\text { (Moderate Positive } \\
\text { Relationship) }\end{array}$ \\
\hline $\begin{array}{l}\text { Academic Performance } \\
\text { \& Motivation Level }\end{array}$ & 0.31 & 0.814 & 0.228 & Reject Ho & $\begin{array}{l}\text { Significant Relationship } \\
\text { (Moderate Relationship) }\end{array}$ \\
\hline $\begin{array}{l}\text { Table } 4 \text { presents } t \\
\text { learn and academic perfor } \\
\text { moderate positive relation } \\
\text { their moderate academic } p \\
\text { moderate positive relations } \\
\text { their moderate academic } p \\
\text { moderate positive relations } \\
\text { with their academic perfor } \\
\text { significant with a moderat } \\
\text { pupils is aligned with their }\end{array}$ & $\begin{array}{l}\text { test of } \\
\text { ce. In } \\
\text {. Thi } \\
\text { orman } \\
\text {. This } \\
\text { orman } \\
\text { This }\end{array}$ & $\begin{array}{l}\text { ationship bet } \\
\text { ual learning } \\
\text { eans that the } \\
\text { In auditory l } \\
\text { ans that the } \\
\text { The verbal s } \\
\text { ans that the } \\
\text { ms of kinest } \\
\text { ationship. Th } \\
\text { formance. }\end{array}$ & $\begin{array}{l}\text { yen learning st } \\
\text { yle, the } r \text { valu } \\
\text { oderate visual } \\
\text { ning style, the } \\
\text { derate auditor } \\
\text { e has the } r \text { val } \\
\text { oderate verbal } \\
\text { tic learning sty } \\
\text { means that th }\end{array}$ & $\begin{array}{l}\text { s and academ } \\
\text { s } 0.37 \text { which } \\
\text { yle of the Gr } \\
\text { value is } 0.33 \\
\text { kill of the Gr } \\
\text { of } 0.30 \text { whic } \\
\text { kill of the Gr } \\
\text { the value of }\end{array}$ & $\begin{array}{l}\text { performance; motivation to } \\
\text { erpreted as significant with } \\
\text { Five pupils matched with } \\
\text { erpreted as significant with } \\
\text { Five pupils is in line with } \\
\text { s read as significant with a } \\
\text { Five pupils is coordinated } \\
\text { s } 0.30 \text { which understood as } \\
\text { etic skill of the Grade Five }\end{array}$ \\
\hline
\end{tabular}


In terms of the motivation to learn, the value of $r$ is 0.31 which understood as significant with moderate relationship. It means that the motivation to learn has a significant relationship to the Grade Five pupils' academic performance. The pupils' motivation to learn is vital to improve the academic performance.

The computed value or $\mathrm{t}$ in visual learning style and academic performance is 1.041 which is higher than the table value of 0.228 and the $r$ is 0.37 which interpreted as moderate positive relationship and so the null hypothesis is rejected. Therefore, there is a moderate positive relationship between the visual learning style and academic performance.

In the computed value or $\mathrm{t}$ in auditory learning style and academic performance is 0.892 is higher than the table value of 0.228 and the $\mathrm{r}$ value is 0.33 which interpreted as moderate positive relationship and so the null hypothesis is rejected. Therefore, there is a significant relationship between the auditory learning style and academic performance of the Grade Five pupils.

In the computed value or $t$ in verbal learning style and academic performance is 0.667 is higher than the table value of 0.228 and the $r$ value is 0.30 which interpreted as moderate positive relationship and so the null hypothesis is rejected. Therefore, there is a significant relationship between the verbal learning style and academic performance of the Grade Five pupils.

In the computed value or $\mathrm{t}$ in kinesthetic learning style and academic performance is 0.664 is higher than the table value of 0.228 and the $r$ value is 0.30 which interpreted as moderate positive relationship and so the null hypothesis is rejected. Therefore, there is a significant relationship between the kinesthetic learning style and academic performance of the Grade Five pupils.

In the computed value or $\mathrm{t}$ in motivation to learn and academic performance is 0.814 is higher than the table value of 0.228 and the $\mathrm{r}$ value is 0.31 which interpreted as moderate positive relationship and so the null hypothesis is rejected. Therefore, there is a significant relationship between the motivation to learn and academic performance of the Grade Five pupils.

Based on the test of relationship, the null hypothesis is disproved. Therefore there is significant relationship between the learning styles and academic performance; and motivation to learn and academic performance of the Grade Five pupils.

From the study of Carbonel, the visual is the most dominant learning style, then followed by auditory and tactile (kinesthetic) as less dominant. It shows the learners' learning styles have significant relationship to their academic performance.

Cools, Vanderheyden and Backhaus' study entitled "The Impact of Student Style Differences and Motivation on Learning Outcomes in Management Education: An International Inquiry" shows that the Student Style Differences (Learning Styles), Motivation and Learning Outcomes (Academic Performance) have significant relationship. The study also conveys that outstanding learning outcomes of the students depend on their styles and interest.

Based from other related studies mentioned, learning styles, motivation to learn and academic performance have significant relationship to each other. Therefore, they play a vital role in shaping the pupils' success.

\section{Conclusion}

Based on the salient findings of the study, the Grade Five pupils have different preferred learning styles. Their most dominant learning styles are visual and auditory and the less dominant are verbal and kinesthetic. Therefore, the Grade Five pupils are good in viewing and listening. To their less preferred styles, they can be improved with a series of activities. The motivation to learn of the Grade Five pupils is high. This means that they are interested to learn. Their academic performance is satisfactory. This means that Grade Five pupils are good in 
the class. The Grade Five pupils' learning styles have significant relationship to their academic performance. Their motivation to learn has also significant relationship to their academic performance. Therefore, learning styles and motivation to learn are necessary in improving the academic performance of the Grade Five pupils.

\section{Recommendation}

following:

In the research process, if there are researchers who will replicate the study, the researcher recommends the

1. The interpretation of data is based on individual ratings only. It could have been based on the tool by items so it would be detailed. But the realization was late since the data were already interpreted.

2. The researcher included the entire thirty seven (37) Grade Five pupils in the research. But for replication covering big population, the researchers can use random selection.

3. The future researchers can include other pupils from other grade levels.

4. The future researchers are free to use any tools that are suited to the needs of the pupils.

\section{References}

[1] Annie Ward; Howard W. Stoker; Mildred Murray-Ward (1996), "Achievement and Ability Tests - Definition of the Domain", Educational Measurement, 2, University Press of America, pp. 2-5, ISBN 978-0-7618-0385-0

[2] Barberos, M. et al (2016) "The Effect of the Teacher Style on Students' Motivation", NYU Steinhardt - Applied Psychology-246 Greene Street, 8th Floor, New York, NY 10003

[3] Bernardo, Allan B. I., Zhang, Li-Fang and Callueng, Camel M. (2001) "Thinking Styles and Academic Achievement among Filipino Students" The Journal of Genetic Psychology, 163(2), 149-163.

[4] Boydak, A. (2006) Learning Styles. Istanbul: Beyaz Publishing.

[5] Çalışkana, H. and G. Kılınçb (2012) Procedia - Social and Behavioral Sciences 55. Elsevier Ltd. Selection

[6] Carbonel, Loneza Gas-ib (2013) "Learning Styles, Study Habits, and Academic of College Students at Kalinga-Apayao State College, Philippines", International Journal of Advanced Research in Management and Social Sciences ISSN: 2278-6236.

[7] Ching-Chun Shih (1998) "Relationships among Student Attitudes, Motivation, Learning Styles, Learning Strategies, Patterns of Learning and Achievement: A Formative Evaluation of Distance Education via Web-based courses”. Iowa State University, Ames, Iowa.

[8] Coffield, Frank, et al (2004) Learning Styles and Pedagogy in Post 16 Learning: A Systematic and Critical Review, Learning and Skills Research Centre, www.LSRC.ac.uk.

[9] Cools, E. et al (2014) "The Impact of Student Style Differences and Motivation on Learning Outcomes in Management Education, UCL Institute of Education", University College London ISSN 1746-9082.

[10] Darling, Nancy (2005-10-01). "Participation in Extracurricular Activities and Adolescent Adjustment: Cross-Sectional and Longitudinal Findings". Journal of Youth and Adolescence. 34 (5): 493-505. doi:10.1007/s10964-005-7266-8. ISSN 0047-2891

[11] Fleming, N., and D. Baume, (2006) “Learning Styles Again: VARKing up the right tree!”, Educational Developments, SEDA Ltd, Issue 7.4, p4-7.

[12] Fleming, Neil D. (2012) Teaching and Learning Styles: VARKStrategies, www.vark-learn.com

[13] Fry, Heather, et al (2009) A Handbook for Teaching and Learning in Higher Education Enhancing Academic Practice, Third edition Routledge 270 Madison Ave, New York, NY 10016

[14] Ghaedi, Z and Jam, B (2014) "Relationship between Learning Styles and Motivation for Higher Education in EFL Students". Theory and Practice in Language Studies. Finland: Academy Publisher. doi:10.4304/tpls.4.6.1232-1237.

[15] Kazu, Ibrahim Yasar (2009) "The Effect of Learning Styles on Education and the Teaching Process", Journal of Social Sciences 5(2): 8594, 2009 ISSN 1549-3652 Science Publications.

[16] Kolb, D. A. (1984) Experiential learning: Experience as the Source of Learning and Development (Vol. 1). Englewood Cliffs, NJ: PrenticeHall. 
[17] Lucas, Rochelle Irene et al (2010) "A Study on the Intrinsic Motivation Factors in Second Language Learning Among Selected Freshman Students", Philippine ESL Journal, Vol. 4, Time Taylor International ISSN 1718-2298.

[18] McLeod, S. A. (2013). "Kolb - Learning Styles”. Retrieved from www.simplypsychology.org/learning-kolb.html.

[19] Oliveros Pablo et al (2016) "The Relationship between Learning Styles and Motivation to Transfer of Learning in a Vocational Training", http://dx.doi.org/10.1016/j.sumpsi.2016.02.001.

[20] Oxford, Rebecca L. (2003) “Language Learning Styles and Strategies: An Overview” Learning Styles \& Strategies/Oxford,GALA

[21] Pashler, Harold, et al (2009) “Learning Styles Concepts and Evidence”, Psychological Science in the Public Interest, p105-117.

[22] Romanelli, F. et al (2009) "Learning Styles: A Review of Theory, Application, and Best Practices", American Journal of Pharmaceutical Education v. 73(1); PMC269088.

[23] Tonog, Merle N. (2014) "The Effect of Teaching and Learning Styles on Students' Academic Achievement in General Chemistry 1 at the University of Eastern Philippines" International Journal of Recent Advances in Multidisciplinary Research Vol. 02, Issue 03, pp.03230324.

[24] Ya-Nan He (2009) “Motivational Strategies: Students' and Teachers' Perspectives”. Kent State University.

[25] Velasco, Arnulfo G. et al (2015) "International Journal of Multidisciplinary”, Academic Research, Vol. 3, No. 1, 2015, ISSN 2309-3218 